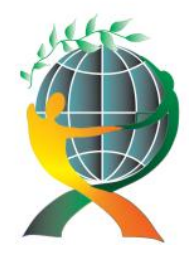

$$
\begin{gathered}
\text { (online) }=\text { ISSN } 2285-3642 \\
\text { ISSN-L }=2285-3642
\end{gathered}
$$

Journal of Economic Development, Environment and People

Volume 1, Issue 2, 2012

URL: http://jedep.spiruharet.ro

e-mail: office jedep@spiruharet.ro

\title{
Consequences of Climate Change for agriculture and nature in the Netherlands
}

\author{
Jeroen Arends \\ Wageningen University, the Netherlands, \\ Email address: jeroenbm.arends@wur.nl
}

\begin{abstract}
After the publication of the IPCC reports on climate change, the Dutch Meteorological Institute of the Netherlands (KNMI) conducted a study on the consequences of climate change for the Netherlands. Four different scenarios regarding the rise in temperature and their consequences have been developed. Other institutes have elaborated more on these scenarios, making predictions on the effects of climate change on nature and agriculture for the Netherlands. Overall conclusions are that climate change will have dramatic consequences for nature, agriculture and Dutch society in general, being so exposed to rising sea levels. Depending on the scenario, consequences have various gradients of impacts and effects. In general, it is estimated that winters will be softer and wetter, and that summers will be hotter and drier with intermittent torrential rains that can have dire consequences for agriculture and nature. Growing seasons will start earlier and will last longer which could lead to mismatches in species interaction. Species of various kinds will suffer the effects of climate change and will disappear from the Netherlands altogether, either through extinction or by moving away north. Other warmth loving species from the south of the Netherlands will move upwards towards the country leading to possible threats to indigenous species.
\end{abstract}

Keywords: Agriculture, climate change, climate scenarios, landscape, nature, the Netherlands

JEL Codes: Q10, Q54, N54 


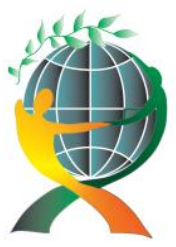

\author{
(online) $=$ ISSN $2285-3642$ \\ ISSN-L = $2285-3642$ \\ Journal of Economic Development, Environment and People \\ Volume 1, Issue 2, 2012 \\ URL: http://jedep.spiruharet.ro \\ e-mail: office jedep@spiruharet.ro
}

\title{
1. Introduction
}

In recent years the Netherlands has been confronted by the effects of climate change. Temperatures and amounts of precipitation have risen considerably. What exactly the consequences will be is still subject of research and debate but some trends are already visible. Climate change will affect many parts of society. This paper will explore the effects for agriculture and nature. A description of the historical development of the Dutch landscape and nature will be given first, further expanded by an overview of other aspects of environmental degradation that affect the current landscape and nature in the Netherlands. This is important in order to understand the context on which climate change will have its effect.

The paper will then describe the changes in temperature and precipitation observed followed by a description of four scenarios developed by the Dutch Meteorological Institute which make projections of future temperatures and amounts of precipitation. Next, the effects of climate change on agriculture and nature will be discussed. Lastly, the paper will end with conclusions.

This paper is the result of a literature review and for the study a variety of documents of mostly Dutch institutes and authors was conducted. All sources, but one, were in the Dutch language. For this paper the author has translated the found sources into the English language.

\section{Historical development of landscape and nature in the Netherlands}

\subsection{Landscape and nature throughout the centuries}

The landscape in the Netherlands has been greatly affected by the choices made in the past. Probably nowhere in the world had humans so much effect on the landscape and nature (Londo, 1997). The landscape is managed in order to combine multiple functions like urbanization, agriculture, industry, recreation and nature, which is required in such a densely populated country. There is truth in saying that the Dutch -at least partly- created their country. However, one of the best kept secrets of the Netherlands is that the Dutch themselves are responsible that a large part of their country lies below sea level. This part of the study will show how these changes came about and what their effects are. It will set the context on which climate change happens. Later in the study, these effects will be elaborated on.

Before settlements, the country's landscape consisted for $70 \%$ out of peat (Roos et al., 2004) and ancient forests. Peat is the remains of plants which accumulated over time. The wet conditions of the Dutch landscape assured that the peat was not exposed to oxygen and could therefore mineralize. Early settlers started to clear the forest and excavate the peat, converting the land into agricultural land. Trees were cut in order to create space for cattle. Water was drained away. The peat was exposed to oxygen and mineralized, creating fertile farmland. Farmland was used until the land was exhausted, to be replaced with other converted land. This is how over the centuries, peat and forests were converted into agricultural lands (Londo, 1997). 


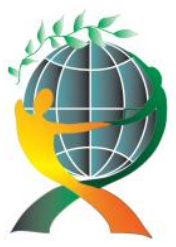

\author{
(online) $=$ ISSN $2285-3642$ \\ ISSN-L = $2285-3642$ \\ Journal of Economic Development, Environment and People \\ Volume 1, Issue 2, 2012 \\ URL: http://jedep.spiruharet.ro \\ e-mail: office jedep@spiruharet.ro
}

The consequence of this was that land subsided due to compaction of soil. More water needed to be pumped out in order to keep the land suitable for agriculture. This at first did not pose a problem since the land was still well above sea level but from the $10^{\text {th }}$ century onwards the population of the Netherlands rose steadily and more land needed to be converted to agricultural land and this land needed to be kept dry. Elaborate systems of ditches and canals were constructed to lead the water away to the rivers and eventually to the sea. This process lasted for centuries leading to the vicious circle of pumping water out in order to convert peat into farmland and to continue pumping in order to keep that farmland not submerged with water. With the introduction of windmills this process really took off. This led to the famous Dutch landscape with her characteristic ditches, canals and dikes which created so called polders: pieces of reclaimed land protected by dikes converted into agricultural land (Beekman et al., 2010)

Another development that took place during the centuries was protecting the ever decreasing level of land against floods. Floods came predominately from the sea but also from the rivers. Dunes were raised and strengthened along the coastline, dikes were build along rivers and elaborate systems of canals and waterways pumped water from ditches to canals, rivers and eventually to the sea. Nevertheless, this did not prevent floods from occurring and in 1953 a large flood took place in the South West of the country killing 1,835 people and causing massive damage. This tragedy led to the formation of the so-called Delta plan which conducted projects to further strengthen the coastline and build dams and dikes in the South West. The Dutch thought once again that they were safe but then the threat came from another direction: the rivers. During the 90s of the last century, excess melt and rain water from the rivers threatened to flood large parts of the eastern part of the country. Subsequent summers were too dry and weakened the dikes made out of peat material. Dikes were too weak and needed to be strengthened. However, it seemed that building higher and stronger dikes were not the solution. It was decided to expand the capacity of the river to handle large amounts of water by giving the rivers space to 'breathe' that is, the rivers were given a chance to deal with excess water by converting neighboring land into floodplains. Rivers were allowed to flood these lands in order to get the pressure off.

\title{
2.2. Effects of the changing landscape on nature
}

The mentioned interventions in the Dutch landscape of course had consequences for nature. Primeval forests in the Netherlands disappeared altogether and apart from some areas, no large forests remain. Those remained are a mix of leafed and coniferous forests with introduced tree species like the Scottish pine. Animal species that found habitat in these forests also disappeared. Examples are wolf, bear and red deer.

Currently, the Netherlands counts many different types landscapes each with its own particular kind of vegetation and corresponding fauna. Unique are the salt water landscapes and heath with their ecosystems. Some of these ecosystems also disappeared although initiatives to restore them are currently being conducted. 


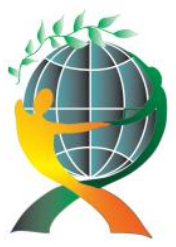

\author{
(online) $=$ ISSN $2285-3642$ \\ ISSN-L = $2285-3642$ \\ Journal of Economic Development, Environment and People \\ Volume 1, Issue 2, 2012 \\ URL: http://jedep.spiruharet.ro \\ e-mail: office jedep@spiruharet.ro
}

The largest effects on nature come from agriculture and urbanization. Agriculture converted natural land into land used for monoculture crops or livestock. After WWII, agriculture in the Netherlands really took off when a system that converted many small plots of land into big pieces was introduced. The characteristic borders between plots of lands consisting out of hedges disappeared altogether or were replaced with barbed wire for convenience. This led to a loss of not only landscape beauty but also to a loss of biodiversity because habitats and corridors were lost.

The irony is that in the past $70 \%$ of the country was covered with peat and forests containing many ecosystems and offering habitat to many species, nowadays $70 \%$ of the country is covered with grassy meadows often used for monoculture agriculture leading to loss of habitat and biodiversity. Overall it can be concluded that the Dutch landscape has changed dramatically over the centuries due to agriculture, industry and urbanization. The effects on nature have also been quite dramatic with loss of biodiversity and habitat. Numerous aspects linked to historical and economic development are contributing factors to the state of nature in the Netherlands. These are: subsidence of land, acidification due to SO2 emissions, eutrophication, pollution and landscape fragmentation. Two factors are linked to the climate change:

Rising sea level and increasing rain and melt water in the rivers due to climate change;

Periods of droughts alternated with excessive torrential rain

They will be elaborated in this study. It is within the above pictured context that climate change will affect species chances of survival and abilities to adapt to climate change.

Before awareness of the effects of climate change arose, the Netherlands already started dealing with the other causes of environmental damage and damage to nature. Like many other countries it signed the LRTAP convention to reduce emissions of $\mathrm{SO} 2$ and other acidifying gasses. Other agreements governing pollution were also signed. Agriculture had to limit the use of fertilizers and the unrestrained spreading over the land of manure. However, agriculture has a strong political pillar making change a difficult and slow process.

\title{
2.3. Restoring nature
}

A multitude of nature restoration projects have been conducted over the years combating the effects of acidification, eutrophication and dehydration. That often involves removing top layers of soil which over time had accumulated too many nutrients leading to dominance of nutrient loving species, often grasses. Other projects involve restoring and widening natural meandering water flows that were previously made straight to accommodate agriculture. Meandering increases the holding capacity of these water bodies. This leads to a multitude of different aquatic and embankment habitats and ecosystems accommodating many species of insects, fish and other water creatures, creating corridors between separated ecosystems and habitats. As much as possible in these projects, the historic situation as it once was is being restored. This often has various success rates. Restoring natural areas requires careful planning, careful observation and a great deal of luck with local conditions and weather (Bouwman et al., 2011). 


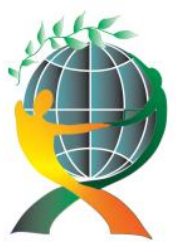

\author{
(online) $=$ ISSN $2285-3642$ \\ ISSN-L = $2285-3642$ \\ Journal of Economic Development, Environment and People \\ Volume 1, Issue 2, 2012 \\ URL: http://jedep.spiruharet.ro \\ e-mail: office jedep@spiruharet.ro
}

In order to preserve and increase nature and biodiversity, a series of ecological networks were developed with robust connections between them resulting in the country's Ecological Main Structure (EHS), see Annex IV. Farmers were often appointed as 'stewards of nature' and compensated for the use of their land or for not moving their fields' too early thereby allowing birds on their lands to have nests. Subsequent governments had invested millions of Euro in the EHS and the structure is estimated to be half way. Unfortunately, the new government of the Netherlands has put a stop on the structure possible under pressure from the agricultural lobby and against the directives for habitats of the Europeans Union. The EHS which served as an example for the EU's Natura2000 ecological networks is now under pressure and the plans to stop investing in it will most likely collide with the EU.

\title{
3. Climate change in the Netherlands
}

\subsection{Temperature and precipitation changes in the Netherlands}

The average temperature in the world has risen with 0.4 to 0.7 o C since 1900 (MNP book). Compared, the average temperature in the Netherlands has risen with 1.7 o C since 1900 and the precipitation increased with 18\% (Vonk et al., 2010). This is due to changes in wind and weather conditions over the Atlantic Ocean caused by climate change.

The last 20 years the temperature in the Netherlands has risen with 0.7 o C (Roos et. al., 2004) and the temperatures in the years 2006 and 2007 were just as high as those measured at the end of the 20th century in the middle of France (Vonk et al., 2010). The first decade of the 21st century has been the warmest since measurements of temperature began (Vonk et al., 2010) and the summer of 2010 was the warmest ever measured. The warming of the Netherlands is noticeable in all seasons but not equally spread out over all seasons. In general there is an increase in the number of warm extremes and a decrease in the number of cold extremes.

The water temperatures also rose. In fens the water temperature rose quite dramatically over the last 20 years by almost $2 \circ \mathrm{C}$. The water temperature in the river Rhine in the last century rose with 3 o $\mathrm{C}$ of which 2 o $\mathrm{C}$ were accountable by the discharge of cooling water from power plants. Sea water temperature rose with 1 o C (Lenderink et al., 2008 in Vonk et al., 2010). Temperature at the bottom of the North Sea rose 1.5 o C, as measured at the end of the 1980s (Hiddink \& Ter Hostede, 2008 in Vonk et al, 2010).

In the period $1906-2005$ the average amount of precipitation has risen with $18 \%$ in the Netherlands, especially in winter $(+26 \%)$, spring $(+21 \%)$ and autumn $(+26 \%)$. The amount barely changed in summer (KNMI, 2006 in Vonk et al., 2010). The increase is attributed to changes in wind patterns along the coast and by the warming of sea water. Especially coastal areas have become wetter (KNMI, 2008 in Vonk et al, 2010). The frequency and intensity of torrential rain have increased, especially in winter time. Just as with average precipitation, extreme precipitation has increased especially in coastal areas. 


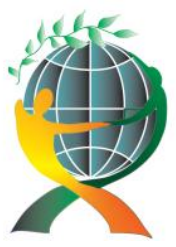

\author{
(online) $=$ ISSN $2285-3642$ \\ ISSN-L = $2285-3642$ \\ Journal of Economic Development, Environment and People \\ Volume 1, Issue 2, 2012 \\ URL: http://jedep.spiruharet.ro \\ e-mail: office jedep@spiruharet.ro
}

\title{
3.2. Climate change scenarios
}

Following the reports of the IPCC on climate change and the measured national changes in temperature and precipitation, the Dutch Meteorological Institute developed four different climate scenarios for the Netherlands.

These scenarios make projections of the possible effects of global climate change on temperature, precipitation, wind and other climatic conditions for the Netherlands. Projections were made for the year 2050 and 2100.

The climate in the Netherlands is very much determined by the global climate and by the western winds coming from the Atlantic Ocean (KNMI, 2009).

Overall, all scenarios project the following effects for the Netherlands: 1

The temperature will continue to rise;

Sea level will continue to rise

Winters will be more moderate and wetter;

Summers will be drier leading to periods of drought;

The calculated change in wind will be small compared to the natural fluctuations;

Sporadic but heavy torrential rains in summer.

The severity of the effects of climate change is determined by the relative rise in temperature. In the most modest scenario the global temperature for the year 2050 rises with 1oC compared to 1990, in the worst scenario the temperature rises with 2 o C. For the year 2100 temperature increments of respectively 2 and 4 oC compared with 1990 are expected for the "best" and "worst" case scenarios. The meteorological institute calculated for all scenarios what the highest, lowest and average temperature and amounts of precipitation per season will be. In all scenarios the temperatures will go up. The number of days with precipitation will increase in winter and also the amount of rain will increase. In summer the number of days with precipitation will decrease while at the same time evapotranspiration will increase leading to droughts. This will be alternated with heavy torrential rains leading to floods and potential failed harvests.

Finally, the Institute also projected the sea level rise under each scenarios for the years of 2050 and 2100. For 2050 this will be respectively $15-25 \mathrm{~cm}$ and $20-35 \mathrm{~cm}$ for the best and worst case scenario, while for 2100 this will be $35-60 \mathrm{~cm}$ and $40-85 \mathrm{~cm} 2$.

Based on the studies of the IPCC and the Dutch Meteorological Institute, other studies to the effects of climate change were conducted. These studies along with economic and demographic developments led to projections for society as a whole. This report will only deal with the consequences for agriculture and

\footnotetext{
${ }^{1}$ www.knmi.nl/klimaatscenarios/

${ }^{2}$ dito
} 


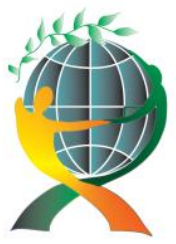

\author{
(online) $=$ ISSN $2285-3642$ \\ ISSN-L = $2285-3642$ \\ Journal of Economic Development, Environment and People \\ Volume 1, Issue 2, 2012 \\ URL: http://jedep.spiruharet.ro \\ e-mail: office jedep@spiruharet.ro
}

nature. However, choices made regarding other societal functions can also have effects on agriculture and nature. These choices are not taken into account in this report.

\title{
4. Effects of climate change
}

\subsection{Agriculture}

In 2008 a study to the effects of climate change for agriculture and nature was conducted by Alterra, the research Institute of Wageningen University. The main effects for agriculture that are to be expected are:

- Changing temperature patterns and rising average temperature

- Changing precipitation patterns and amounts of precipitation

- Rising sea level and associated relative land subsidence leading to rewetting of land due to rising groundwater level (see figure 1)

- Rising sea level and associated salinization of soils

- Rising $\mathrm{CO} 2$ concentrations

(Blom et. al., 2008)

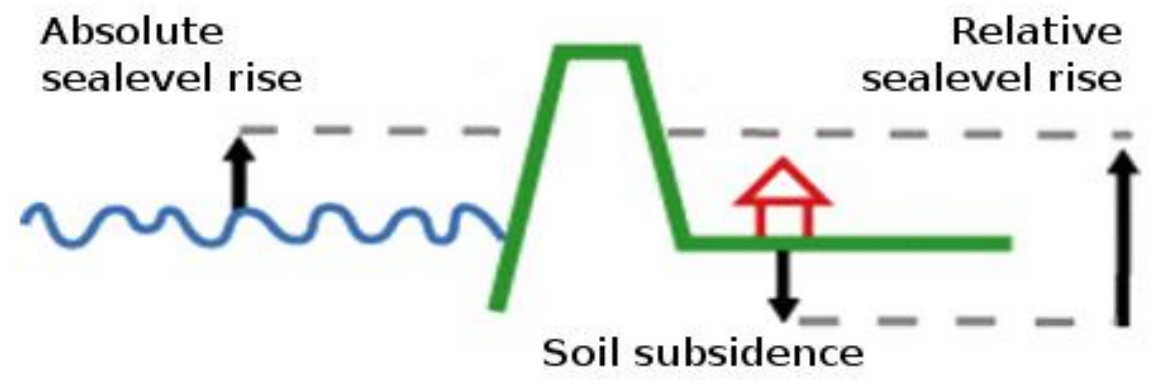

Fig.1: Relation between absolute sea level rise, relative sea level rise and soil subsidence due to soil compaction ${ }^{3}$

The starting point was the overview of the crop distribution in the Netherlands based on which the consequences of the climate change are envisaged, see Annex I.

The Alterra researchers distinguished two types of climate change: structural and incidental. They concluded that the structural climate change in general will have a relatively limited effect on agriculture. Because winters will become more moderate, the growing season will start earlier and last longer leading to an increase in productivity. However due to the moderate winters, pests and diseases will have more

\footnotetext{
${ }^{3}$ www.knmi.nl/klimaatscenarios/
} 


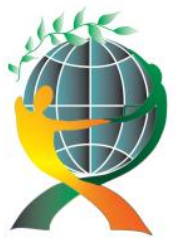

\author{
(online) $=$ ISSN $2285-3642$ \\ ISSN-L = $2285-3642$ \\ Journal of Economic Development, Environment and People \\ Volume 1, Issue 2, 2012 \\ URL: http://jedep.spiruharet.ro \\ e-mail: office jedep@spiruharet.ro
}

chances for survival and become a threat for the next season. Also the climatic conditions will be favorable for un-indigenous weeds (Blom et al., 2008).

The Dutch Meteorological Institute predicts that increased CO2 levels will contribute to a faster and more abundant growth of crops. However, reduced summer rains coupled with evapotranspiration of crops and vegetation in summer due to higher temperatures will lead to dehydration and droughts (de Bilt, 2008).

The incidental effects on agriculture of climate change will be more dramatic than the structural ones. Examples of incidental effects are heat waves and floods. Increased winter rains coupled with increased melt water coming from the rivers and rising salty groundwater can potentially be a threat to crops. This depends on the crop, the growing stage of the crop, the ambient temperature and the dispersion potentials of diseases and plagues. Salinization for instance is damaging for potatoes but beneficial for sugar beets because the salt increases the sugar content in beets (Blom et. al., 2008). The overall sensitivity of agricultural crops in the Netherlands to the consequences of climate change is showed in Annex II. Annex III shows the sensitivity of agricultural crops for the various effects of climate change: Salinization, rewetting, droughts, diseases/plagues, and extreme conditions (Blom et. al., 2008).

Table1: examples of the envisaged effects of climate change are listed

\begin{tabular}{|l|l|}
\hline Salinization & $\begin{array}{l}\text { Climate change will lead to absolute sea level rise while the subsidence of soil due to soil } \\
\text { compaction will add to relative sea level rise (see figure 1). Sea water will penetrate } \\
\text { deeper into the groundwater moving inland, eventually surfacing into the top layers of } \\
\text { soil creating brackish conditions. This saline seepage is damaging for certain crops like } \\
\text { grasses, grains, orchards and potatoes. Like mentioned before, sugar beets will benefit } \\
\text { from more saline groundwater but overall saline seepage is bad for agriculture (Blom et. } \\
\text { al., 2008). }\end{array}$ \\
\hline Drought & $\begin{array}{l}\text { Drought can potentially lead to loss of agricultural production. One way to combat } \\
\text { drought is to irrigate more which will put a strain of the local water reserves which will } \\
\text { already be under threat due to other social demands on the water reserves. A solution to } \\
\text { that is to bring in water from the lakes which however would have negative effects on } \\
\text { nature since this is often water alien to the region. Another effect of droughts can be } \\
\text { denitrification in the soil. This will change the ability of crops and vegetation to absorb } \\
\text { nitrogen which important for growth. }\end{array}$ \\
\hline Rewetting & $\begin{array}{l}\text { Increased precipitation in winter and increased melt water coming from the rivers can } \\
\text { lead to rewetting. Increased pressure from rivers can lead to seepage of water to top soil } \\
\text { layers. } \\
\text { Too much water can lead to the drowning and rotting of crops. It can also play a role in } \\
\text { the leaching of nutrients and pesticides to the surface which would damage water } \\
\text { quality. Rewetting also increases the chances on diseases and plagues. Fungi and } \\
\text { bacteria can spread more easily. Soft winters can increase rates of survival of pests and } \\
\text { increase resistance of pest to pesticides. This can lead to an increase of the number of } \\
\text { predators in the next season. Positive effects of rewetting are decontamination of soil, }\end{array}$ \\
\hline
\end{tabular}




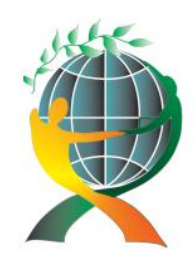

$$
\begin{gathered}
\text { (online) }=\text { ISSN } 2285-3642 \\
\text { ISSN-L = 2285 - } 3642
\end{gathered}
$$

Journal of Economic Development, Environment and People

Volume 1, Issue 2, 2012

URL: http://jedep.spiruharet.ro

e-mail: office jedep@spiruharet.ro

\begin{tabular}{|l|l|}
\hline & less compaction of peat, and the storage of water as buffers (Blom et. al., 2008). \\
\hline $\begin{array}{l}\text { Extreme } \\
\text { conditions }\end{array}$ & $\begin{array}{l}\text { Extreme weather conditions can lead to damage of agricultural crops. Physical damage } \\
\text { by heat waves, torrential rains, strong winds, late frost and hailstorms can inflict severe } \\
\text { damage to grains, vegetables and orchards (Blom et. al, 2008). }\end{array}$ \\
\hline
\end{tabular}

\subsection{Nature}

The effects of climate change on agriculture will also apply to nature. Salinization, droughts, rewetting and extreme weather conditions will also affect species of plants, vegetation and animal species which depend on them. Also there is a chance of increased diseases and plagues (Roos et al., 2004). The severity varies per specie, the stage of growth and other variables. The difference with damage to agricultural crops is that agriculture is much more within the domain of human control than is nature. Natural or half natural landscapes are far more complex and difficult to manage than cultural landscapes like agricultural landscapes.

Even more, the other aspects of environmental degradation (eutrophication, acidification, fragmentation, pollution, dehydration and subsidence of soil) will compound the effects of climate change on nature more than they do on agriculture. Especially the level of fragmentation of nature in the Netherlands will play an important role in the ability of species to deal with the effects of climate change. This following part elaborates the effects of climate change on nature given the current environmental conditions.

\section{Physiological and phenological effects}

Both temperature rise and increased concentrations of $\mathrm{CO} 2$ will have stimulating effects on the physiological processes concerning the growth and decomposition of plant and animal species. Vegetation could start to grow earlier and the season could last longer. However, every plant and animal species will react differently which is dependent on a combination of change in temperature, precipitation, weather patterns and risks.to.drought.

Within specie there is a dependence on location and niche. Although there is considerable uncertainty about the adaptability of species to climate change, the general trend is an advance in the growing and reproductive season. This can lead to a mismatch in food chains (Vos, C. et. al, 2007). Bird or other species that depend on the availability of fruits, seeds or insects can get into trouble when these food sources have already peaked and are no longer available. Migrating birds which depend on timed availability of food sources in different countries can be faced with shortages of food on their migrations (Roos et al., 2004)

\section{Changes in a-biotic conditions}

Higher concentrations of $\mathrm{CO} 2$ lead to more efficient water management and less evapotranspiration in vegetation. This in turn will lead to an increased mineralization of the soil, especially increased availability of 


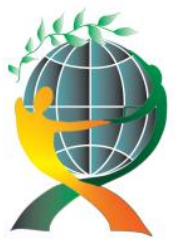

\author{
(online) $=$ ISSN $2285-3642$ \\ ISSN-L = $2285-3642$ \\ Journal of Economic Development, Environment and People \\ Volume 1, Issue 2, 2012 \\ URL: http://jedep.spiruharet.ro \\ e-mail: office jedep@spiruharet.ro
}

nitrogen which will aid in the growth of vegetation. Next to this, an accelerated photosynthesis within some plants will increase biomass production which can have consequences for competitive relations between plant species. This will lead to a roughing of the undergrowth blocking other slow growing plant species. There will be drought and deterioration of water quality near brook and river systems, swamps, wet heath, fens and peat moor. The location of seepage zones can change and pressure of seepage in coastal areas will increase which can lead to the shifting of transition areas between fresh and salt water (Vos, C. et. al, 2007).

Changes in the water regime (currents, length and depth) can influence the habitats and reproductive chances of many species (Roos et al., 2004).

All these changes will have consequences for the functional relations between various species and will lead to shifts in species compositions and in compositions of ecosystems.

\title{
Geographical changes of ecosystems
}

Any change in climate in general will lead to a change in the geographical dispersion of species because the suitable habitats will shift along with the climate. Warmth loving species will move northwards and cold loving species already have been noticed to decrease at the southernmost tip of their living and dispersal habitats. Species preferring the cold will face difficulties to survive in the Netherlands, will be extinct of will move away north from the Netherlands.

Species that prefer warmth and heat will move to the Netherlands from the south and also within the Netherlands a shift of these species will take place (Blom et al., 2008). Species alien to the Netherlands can find habitat in the country and can upset competitive relations between species, overwhelming indigenous species which already have difficulty dealing with climate change and the other environmental problems.

Also, increased weather extremes will have effects on the occurrence, mortality rates and geographical displacements of species. This will have consequences for the reproduction and therefore survival of species (Vos, C. et. al, 2007). Also there is a risk of decreased genetic variation and the risk that species cannot keep up with the speed of climate change (Roos et al., 2004). Any hindering due to fragmentation and lack of migrating or dispersal corridors will compound to this problem (Bennett, 2003). 


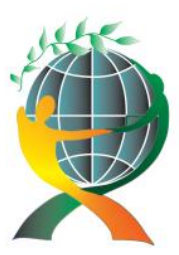

\author{
(online) $=$ ISSN $2285-3642$ \\ ISSN-L = $2285-3642$ \\ Journal of Economic Development, Environment and People \\ Volume 1, Issue 2, 2012 \\ URL: http://jedep.spiruharet.ro \\ e-mail: office jedep@spiruharet.ro
}

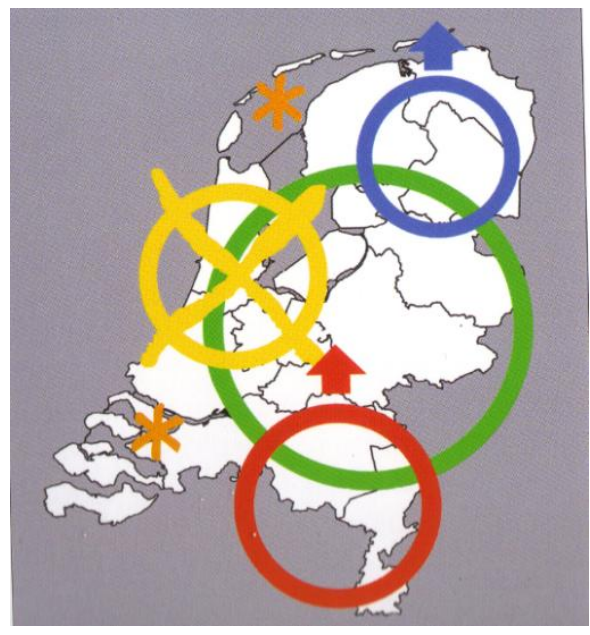

Fig. 2. Four possible reactions of plants and animals to climate change (source: Roos et al., 2004):

Green $=$ Stay, Red $=$ Appearance, Blue $=$ Disappearance, Yellow $=$ Perish, Orange $=$ Emergence of exotic species

\title{
5. Conclusions
}

Nature and the landscape in the Netherlands have changed dramatically over the centuries. Before settlements occurred in the Netherlands, the country was covered for $70 \%$ with peat and forests. Large scale deforestation and excavation of peat to make way for agriculture, urbanization, industry, infrastructure and for energy use turned the Netherlands into a fragmented cultural landscape where nature now only occupies $3 \%$ of total area of the country. The wide use of fertilizers and pesticides coupled with emissions of green house gasses, acid rain gasses and pollution caused by persistent organic pollutants to name a few, led to further environmental deterioration. It is under these conditions that agriculture and nature need to adapt to the effects of climate change.

The effects of climate change for the Netherlands will be a rise in temperature and precipitation throughout the year leading to milder and wetter winters and drier and hotter summers with incidental but heavy torrential rains. Overall, agriculture and nature will be confronted with a combination of salinization, rewetting, droughts, and extreme weather conditions. For agriculture it means that there are higher chances of failed harvests, damage to crops and risks of diseases and plagues. On the other hand growing seasons will be longer and productivity can increase. The agricultural sector needs to adapt to climate change by 


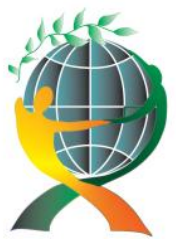

\author{
(online) $=$ ISSN $2285-3642$ \\ ISSN-L = $2285-3642$ \\ Journal of Economic Development, Environment and People \\ Volume 1, Issue 2, 2012 \\ URL: http://jedep.spiruharet.ro \\ e-mail: office jedep@spiruharet.ro
}

altering existing crops to make them more suitable for dry or wet conditions and make them more resistant to diseases and plagues.

Regarding nature, species have already started to move and rather sooner than later species will become extinct or will move out of the Netherlands altogether, while others will stay in the country but will move northwards. New species will move from the south into the country with yet unforeseen consequences for relations between species. Nature can be helped to adapt to climate change by improving mobility opportunities for species by connecting fragmented habitats and by creating migration and dispersion pathways.

The difficulty in a densely populated country like the Netherlands where different social functions compete for the same space is to find the right mix of measures to fight the effects of climate change which will benefit both nature and humans. Agriculture has done a lot of damage to nature and will in the future compete with nature when it comes to measures to adapt to climate change. For instance, droughts will affect agriculture and one solution is to bring in water from other areas which however will not be suitable for local nature. Nature and agriculture can however 'join' forces. Agricultural plagues and pests can be combated by restoring nature areas in and around agricultural areas. The insects living in these areas are natural predators to many agricultural pests. Restoring nature areas can help in retaining water reserves and fight erosion. Restored nature in agricultural areas can attract tourist and provide alternative incomes to farmers.

There is a need for stakeholders like farmers, nature conservationists and national and local governments to come together to combat the effects of climate change while preserving the quality of the landscape and nature.

\title{
6. References
}

[1] Beekman F., Borger G.J., Haartsen A.J., Hacquebord L., Harten J.D.H., de Klerk A.P., Renes J., Schmal ., Stol T., Vervloet J.A.J. (2010): Het Nederlandse landschap, een historisch-geografische benadering. Uitgeverij Matrijs, Utrecht, the Netherlands

[2] Bennett, A.F. (2003): Linkages in the landscape, the role of corridors and connectivity in wildlife conservation. IUCN de Bilt (2008): Klimaateffectschetsboek Drenthe en Groningen. Alterra, KNMI, VU. Wageningen, the Netherlands

[3] Blom, G., Paulissen, M., Vos, C., Agricola H. ( 2008): Effecten van klimaatverandering op landbouw en natuur; nationale knelpuntenkaart en adaptatiestrategieen. Alterra rapport 182. Alterra. Wageningen, the Netherlands

[4] Bouwman J., van den Burg R., Eysink F., Frissen D., Jans R., Jansen A., Koopmans G., Kragt G., Langeveld N., van Os M., Slings R., Verkerk L. (2011): Natuurherstel, 20 jaar effectgerichte maatregelen. Stichting Uitgeverij KNNV, Unie van Bosgroepen. Zeist, the Netherlands

[5] KNMI (2009): Klimaatschetsoek Nederland. Het huidige en toekomstige klimaat. KNMI rapport 223. De Bilt, the Netherlandsondo G. (1997): Natuurontwikkeling. Bos- en Natuurbeheer in Nederland 6. Backhuys Publishers, Leiden, the Netherlands 


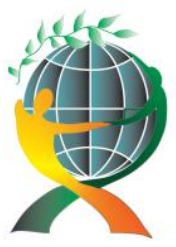

\author{
(online) $=$ ISSN $2285-3642$ \\ ISSN-L = $2285-3642$ \\ Journal of Economic Development, Environment and People \\ Volume 1, Issue 2, 2012
}

URL: http://jedep.spiruharet.ro

e-mail: office jedep@spiruharet.ro

[6] Roos R., Woudenberg S., Dorren G., Brunner E., den Hollander R. (2004): Opgewarmd Nederland, klimaatverandering. Stichting Natuurmedia, uitgeverij Jan van Arkel en Stichting Natuur en Milieu, Amsterdam, the Netherlands

[7] Vonk, M., Vos, C.C., Hoek van der, D.C.J. (2010): Adaptiestrategie voor een klimaatbestendige natuur. Planbureau voor de leefomgeving WUR, The Hague/Bilthoven, the Netherlands

[8] Vos C., Opdam P., Nabuurs G.J., Bugter R., Epe M. (2007): Klimaatverandering en ruimtelijke adaptatie natuur: wat we (niet) weten. Alterra. Wageningen, the Netherlands 


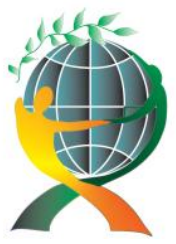

\author{
(online) $=$ ISSN $2285-3642$ \\ ISSN-L = $2285-3642$ \\ Journal of Economic Development, Environment and People \\ Volume 1, Issue 2, 2012
}

URL: http://jedep.spiruharet.ro

e-mail: office jedep@spiruharet.ro

\title{
Annex I
}

Distribution of agricultural crops in the Netherlands (source: Alterra)

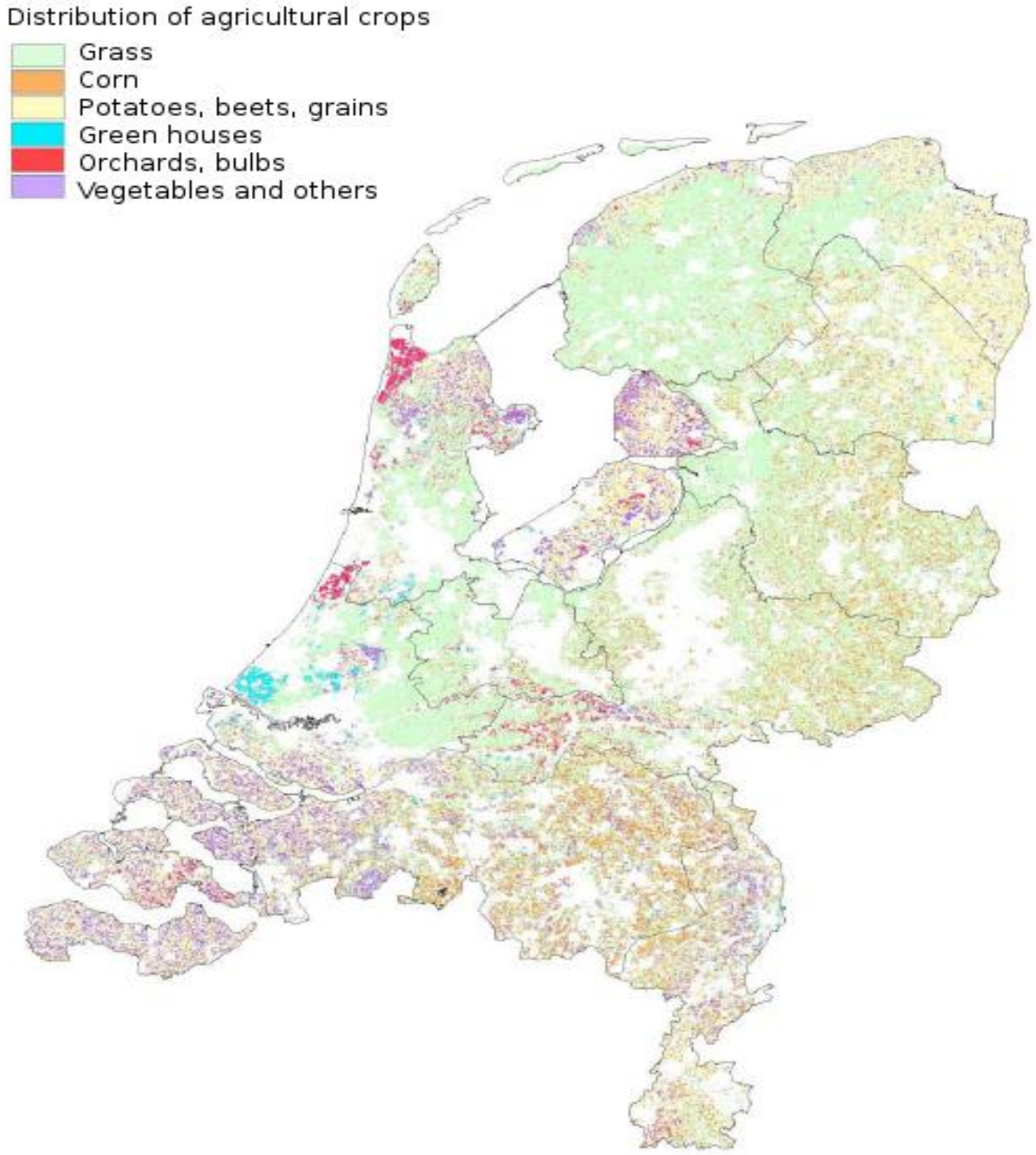




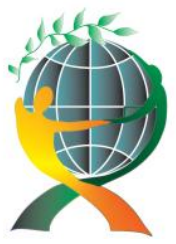

\author{
(online) $=$ ISSN $2285-3642$ \\ ISSN-L = $2285-3642$ \\ Journal of Economic Development, Environment and People \\ Volume 1, Issue 2, 2012
}

URL: http://jedep.spiruharet.ro

e-mail: office jedep@spiruharet.ro

Annex II Sensitivity of agricultural crops in the Netherlands to the consequences of climate change

Not sensitive

Slightly sensitive

Moderately sensitive

Sensitive

Very sensitive

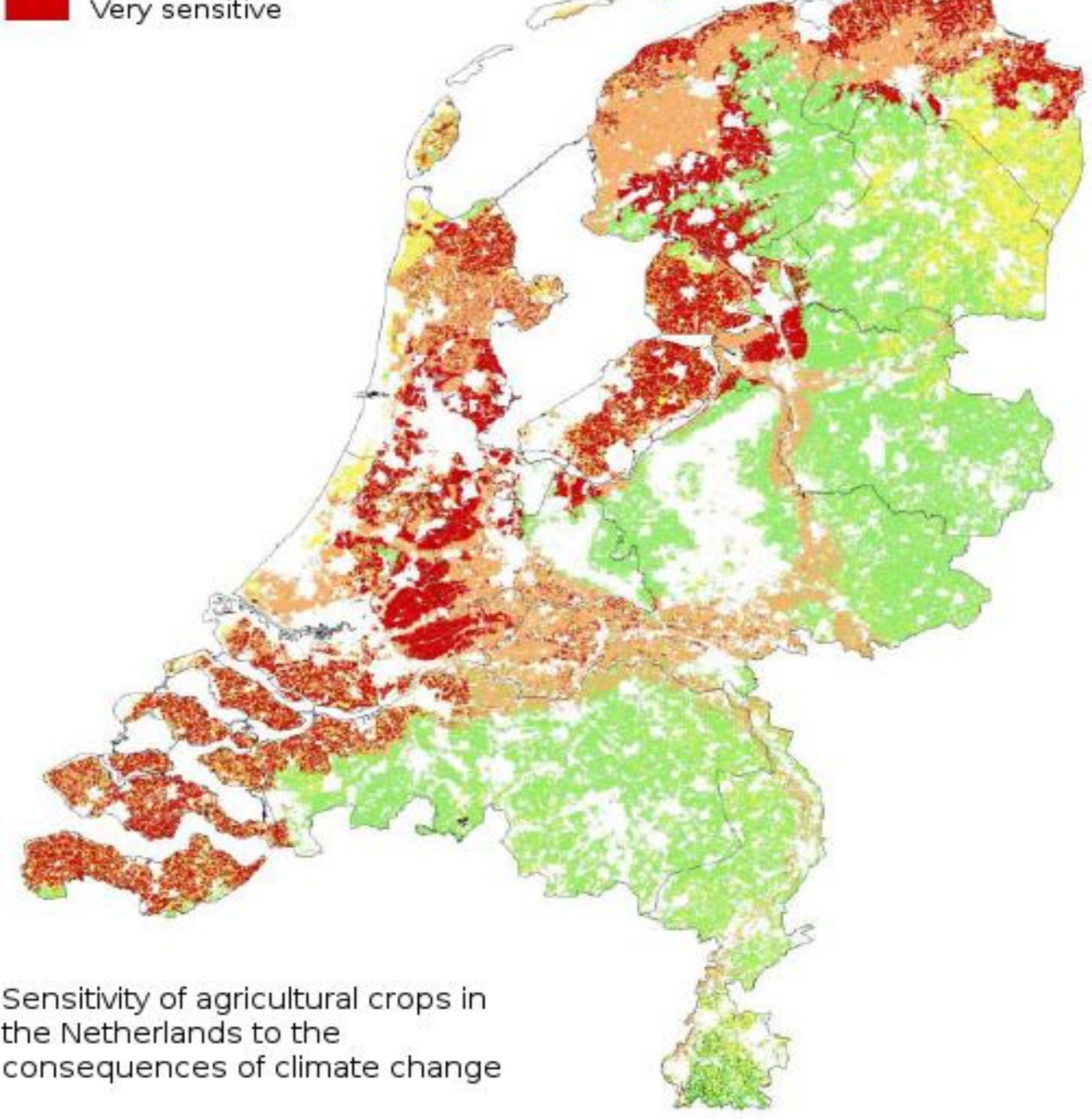




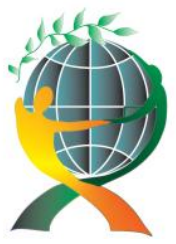

\author{
(online) $=$ ISSN $2285-3642$ \\ ISSN-L = 2285 - 3642 \\ Journal of Economic Development, Environment and People \\ Volume 1, Issue 2, 2012
}

URL: http://jedep.spiruharet.ro

e-mail: office jedep@spiruharet.ro

Annex III Sensitivity maps for extreme conditions

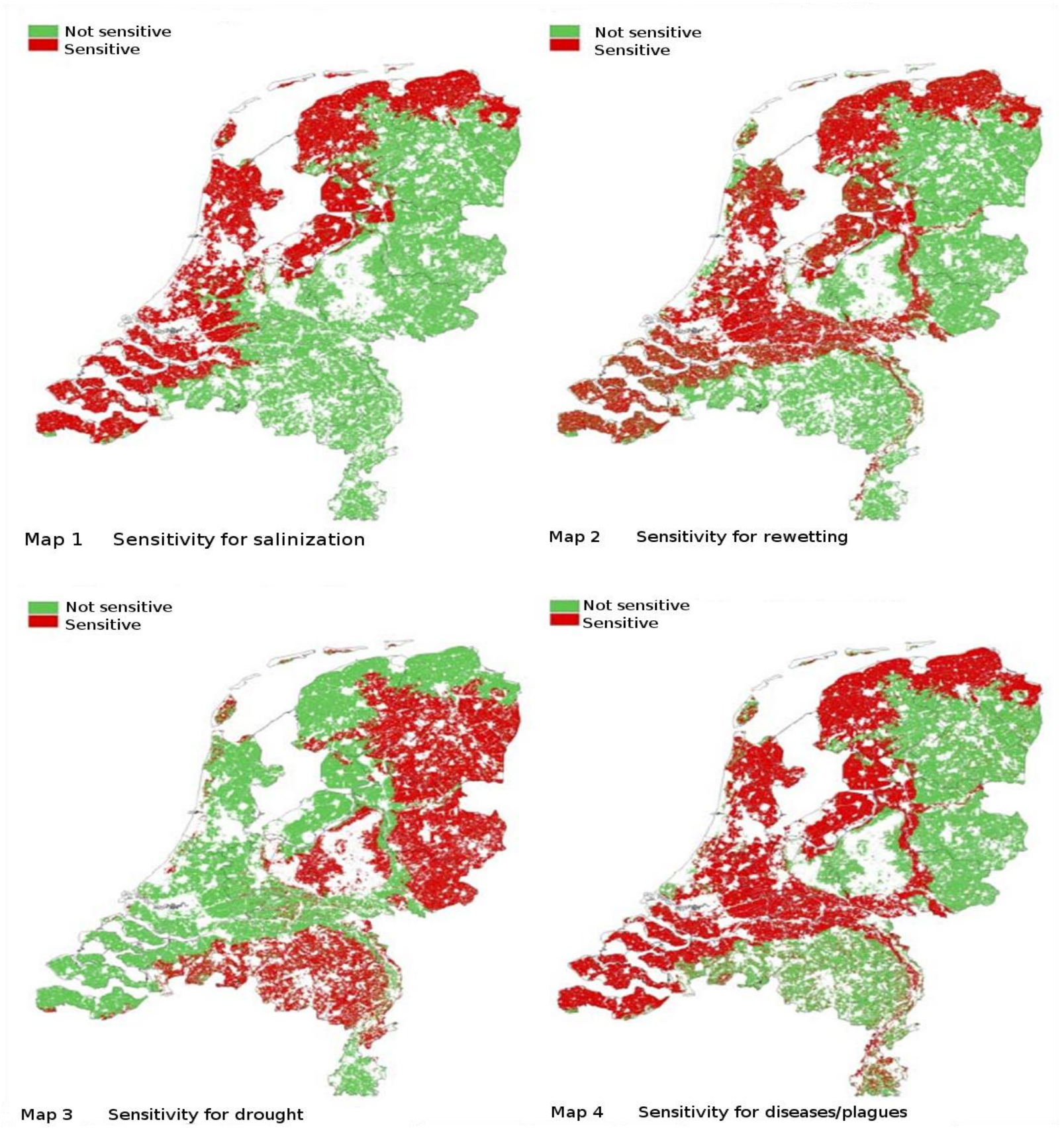




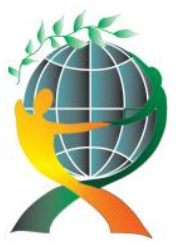

\author{
(online) $=$ ISSN $2285-3642$ \\ ISSN-L = 2285 - 3642 \\ Journal of Economic Development, Environment and People \\ Volume 1, Issue 2, 2012
}

URL: http://iedep.spiruharet.ro

e-mail: office jedep@spiruharet.ro

Annex IV Ecological Main Structure (EHS) in the Netherlands

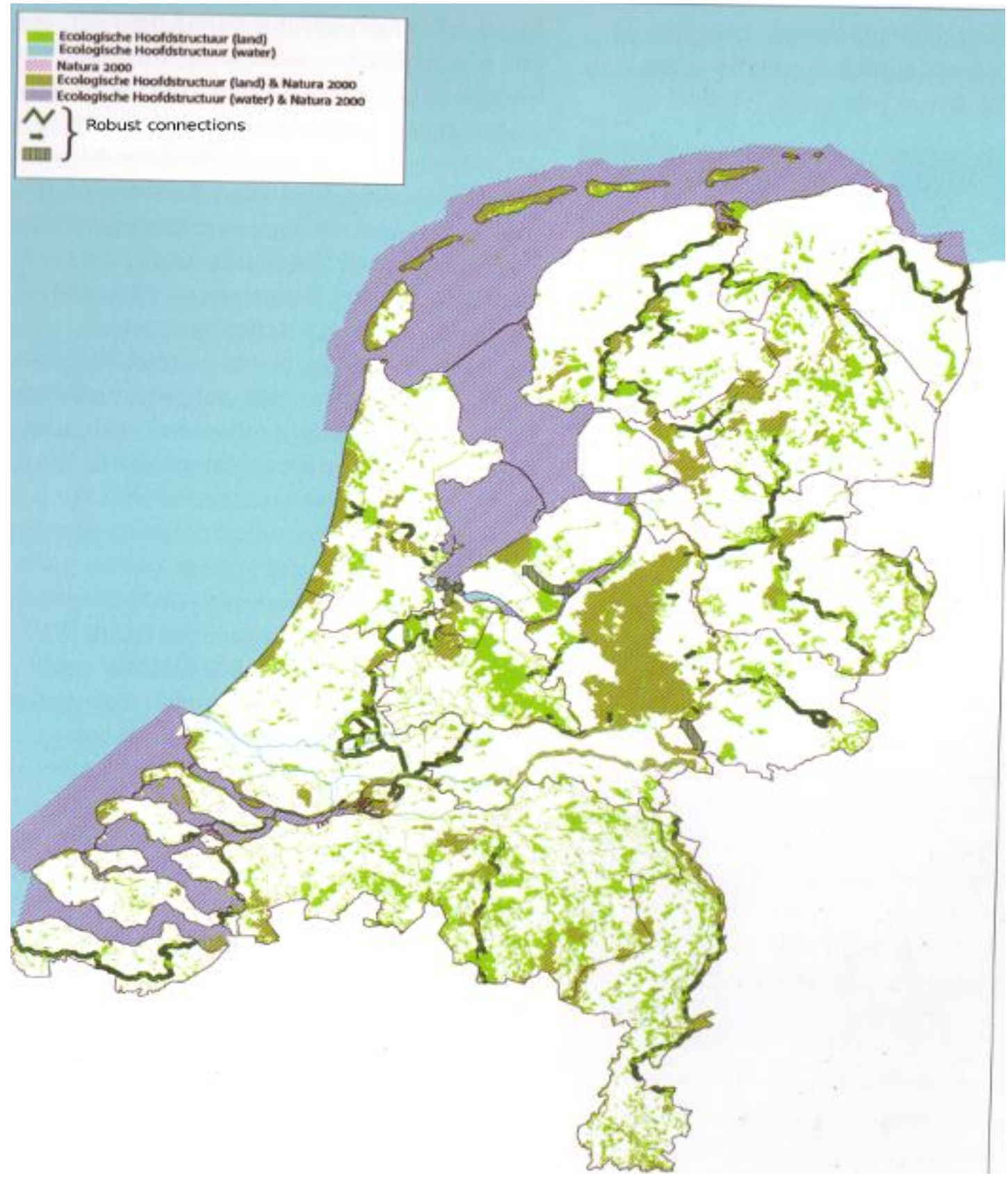

